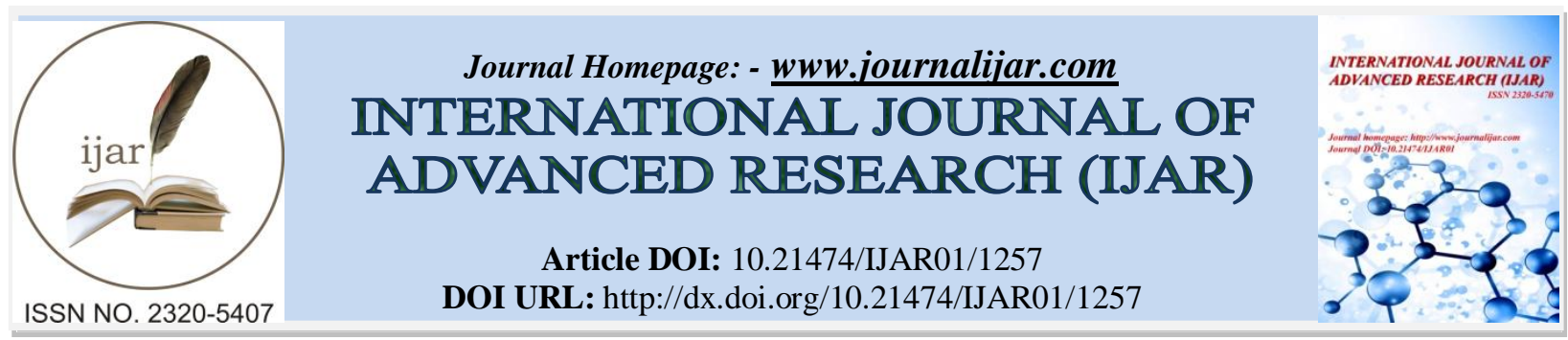

RESEARCH ARTICLE

\title{
BIODIVERSITY OF FUNGAL POPULATION IN FOUR DISTINCT REGIONS OF SHIVNATH RIVER.
}

\author{
*Mrs Shivani Sharma ${ }^{1}$ and Dr. Ashish Saraf ${ }^{2}$ \\ 1. Research Scholar, Department of Biotechnology, MATS University, Raipur, C.G. \\ 2. Associate Professor, Department of Biotechnology, MATS University, Raipur, C.G.
}

\section{Manuscript Info}

Manuscript History

Received: 12 June 2016

Final Accepted: 13 July 2016

Published: August 2016

Key words:-

Shivnath River, PDA, CZA, Lactophenol Cotton Blue, Taxa

\section{Abstract}

Shivnath river water was assessed at three sampling stations with study period of April 2013. The present investigation was carried out on diversity of aquatic fungi from Mehmara Station, Chhattagarh Station, Kotni Station, Pulgaon Chowk (Rajanandgaon Road) Station. The soil samples were examined for fungi by plating method culturing in Potato Dextrose Agar (PDA) medium and Czapek's (dox) Agar (CZA) medium .The isolated fungal strains were identified by Lactophenol Cotton Blue staining. During the study, a total of 44 fungal isolated and identified. The higher fungal taxa that occurred in station-II was observed may be due to unpolluted nature of water and less anthropogenic activities was encountered at this station. Station I, III and IV less number of fungal taxa occurred. This was may be due to the polluted nature of the water and increased anthropogenic activities at this station.

Copy Right, IJAR, 2016,. All rights reserved.

\section{Introduction:-}

Biological diversity refers the variability among living organisms from all sources including terrestrial, marine and other aquatic ecosystems. This includes diversity within the species, between the species and of ecosystems. Soil factors are known to exert effect on the fungal population of microbes. Moisture, $\mathrm{pH}$, porosity, mineral and organic matter contents and their chemical nature, temperature and volatile metabolites produced by accompanying microbes. Soil fungi may occur as free-living organisms or in mycorrhizal association with plant roots. The incidence of the soil fungi vary according to geographic, environmental or bioclimatic factors such as collection site, time of the years relative air, humidity, rainfall, wind speed and proximity to the source where they were produced Oliveira et al., 1993. These factors determine the quality and quantity of the mycobiota existing in terrestrial ecosystems. Fungi are found primarily in the top $10 \mathrm{~cm}$ of the soil. They grow and carry out active metabolism when conditions are favorable which implies adequate moisture, adequate aeration and relatively high concentrations of utilizable substrates. The fungal biodiversity constitute a very large group of organisms virtually found in every ecological niche. Hawksworth (1991) puts that the soil is the typical reservoir of anemophilous fungi and estimated that on a worldwide basis there are about 1.5 million species of fungi.

\section{Material and Methods:-}

Study site Shivnath River is the biggest tributary of Mahanadi river, which it joins in Khargahni in Bilaspur district in Chhattisgarh, India. It has a total course of $290 \mathrm{~km}$. The Latitude of Shivnath River is 21.2859 and The Longitude is 81.2883. Shivnath is main river of District Durg. It originates from Mountain at height of 625 meter at 
Panabaras situated in south western parts of Rajnandgaon and flows towards north east direction. Shivnath River measures length about $345 \mathrm{Km}$. City Durg is situated on east bank of Shivnath River. Climate of the district is of tropical type. Summer is a little bit hotter in the month of April. Rise of temperature begins from the month of March to May. May is hottest amongst other, Maximum Temperature: $39.49^{\circ} \mathrm{C}$, Minimum Temperature: $29^{\circ} \mathrm{C}$ humidity is $27 \%$.

\section{Culture media preparation:- \\ Potato Dextrose Agar medium (PDA) (Aneja, 1996): \\ Peeled potato: $\quad 200 \mathrm{gm}$ \\ Dextrose: $\quad 20 \mathrm{gm}$ \\ Agar Agar: $\quad 20 \mathrm{gm}$ \\ Distilled water: $\quad 1000 \mathrm{ml}$}

The PDA medium was poured into five conical flasks each of $200 \mathrm{ml}$ capacity. The flasks were plugged with cotton and wrapped with aluminum foil. Conical flasks with culture media were sterilized at $121^{\circ} \mathrm{C}$ at 15 psi pressure in an autoclave for about 20 minutes.

\section{Czapek's (dox) Agar medium (CZA) ( Dhingra and Sinclair, 1985)}

$\begin{array}{lc}\text { NaNO3 : } & 2.0 \mathrm{gm} \\ \text { KH2PO4: } & 1.0 \mathrm{gm} \\ \text { KClO3: } & 0.5 \mathrm{gm} \\ \text { MgSO4.7H2O: } & 0.5 \mathrm{gm} \\ \text { FeSO4: } & 0.01 \mathrm{gm} \\ \text { Sucrose: } & 30.0 \mathrm{gm} \\ \text { Agar-Agar : } & 20.0 \mathrm{gm} \\ \text { Distilled water: } & 1000 \mathrm{ml}\end{array}$

Agar-agar was melted in $500 \mathrm{ml}$ of distilled water. All the ingredients were mixed thoroughly. The volume was made up to $1000 \mathrm{ml}$ and sterilized in the previously mentioned fashion.

\section{Isolation of potent microorganisms:-}

The innate fungal strains were isolated from soil samples by serial dilution, pour-plate technique and direct plate method. The mixed cultures were obtained by pour-plating respective diluted samples on potato dextrose agar (PDA) and Czapek Dox agar (CZA) plates amended with sefixime $(50 \mathrm{mg} / 100 \mathrm{ml})$ under sterile conditions at $30 \pm$ $1^{0} \mathrm{C}$ for 7 days. The isolates were stored at $4 \pm 1{ }^{0} \mathrm{C}$ until further use. All isolated fungi were identified as per Alexopoulos and Mims10 and Watanabe11 based on macro and microscopic characteristics. For macromorphological observations, fungi were pure cultured on CZA and PDA for 7 days at $30{ }^{\circ} \mathrm{C}$ in the dark to appraise growth on media with low aw. Identification based on colony morphological study includes form, pattern, quantity of aerial hyphae, diameter, colony colour and texture, margin, elevation, colo-r of colony reverse, presence of exudates, organs formed and soluble pigment. 
Result and Discussion:-

Table 1:- Fungi Isolated From Four Sampling Stations.

\begin{tabular}{|c|c|c|c|c|c|}
\hline S.N. & Fungi Isolated & S1 & S2 & S3 & S4 \\
\hline & Ascomycetes & & & & \\
\hline 1. & Acremonium byssoides & - & - & + & - \\
\hline 2. & Alternaria alternata & + & + & - & + \\
\hline 3. & Alternaria brassicola & + & + & - & + \\
\hline 4. & Aspergillus candidus & - & + & - & + \\
\hline 5. & Aspergillus flavus & - & - & + & + \\
\hline 6. & Aspergillus fumigates & + & - & + & + \\
\hline 7. & Aspergillus nidulanse & + & - & + & + \\
\hline 8. & Aspergillus niger & + & + & - & - \\
\hline 9. & Aspergillus ochraceus & + & + & - & - \\
\hline 10. & Aspergillus oryzae & - & + & + & - \\
\hline 11. & Aspergillus parasiticus & - & + & + & - \\
\hline 12. & Aspergillus terreus & + & + & + & - \\
\hline 13. & Chaetomium funicola & - & - & - & + \\
\hline 14. & Chaetomium globosum & - & - & - & + \\
\hline 15. & Chaetomium indicum & + & + & + & + \\
\hline 16. & Cladosporium cladosporioides & + & + & + & + \\
\hline 17. & Cladosporium oxysporum & + & + & + & + \\
\hline 18. & Curvularia pallescence & + & + & - & - \\
\hline 19. & Drechslera hawaiiensis & - & - & + & - \\
\hline 20. & Drechslera rostrata & - & + & + & - \\
\hline 21. & Drechslera specifer & - & + & - & + \\
\hline 22. & Epicoccum purpurascence & + & + & + & + \\
\hline 23. & Eurotium amestaldomi & + & - & + & + \\
\hline 24. & Fusarium equiseti & + & + & - & + \\
\hline 25. & Fusarium moniliforme & + & - & - & + \\
\hline 26. & Fusarium oxysporum & - & + & + & - \\
\hline 27. & Fusarium pallidoroseum & - & - & + & - \\
\hline 28. & Fusarium solani & - & + & + & - \\
\hline 29. & Neosartoria fischeri & + & + & + & + \\
\hline 30. & Nocosmospora vasinfecta & + & + & + & + \\
\hline 31. & Paecilomyces variotii & + & - & - & + \\
\hline 32. & Penicillium chrysogenum & - & + & - & + \\
\hline 33. & Penicillium citrinum & - & + & + & + \\
\hline 34. & Penicillium oxalicum & + & + & - & - \\
\hline 35. & Phoma glomerata & + & - & + & - \\
\hline 36. & Trichoderma virense & + & + & + & + \\
\hline 37. & Trichoderma viride & - & + & - & + \\
\hline \multirow[t]{2}{*}{38.} & Verticillium alboatrum & - & + & - & - \\
\hline & \multicolumn{5}{|l|}{ Zygomycetes } \\
\hline 39. & Absidia cylindrospora & + & + & + & + \\
\hline 40. & Gongronella butleri & + & + & + & - \\
\hline 41. & Mucor hiemalis & - & + & - & - \\
\hline 42. & Mucor racemosus & + & + & + & + \\
\hline \multirow[t]{2}{*}{43.} & Rhizopus stolonifer & - & + & - & + \\
\hline & \multicolumn{5}{|l|}{ Basidiomycetes } \\
\hline 44. & Rhizoctonia bataticola & - & + & - & + \\
\hline
\end{tabular}

$(+)=$ Present, (-) = Absent, S1- Mehmara Station, S2- Chhattagarh Station, S3- Kotni Station, S4- Pulgaon Chowk (Rajanandgaon Road) Station

In the study, totally 44 species of fungi were isolated by dilution plating technique (Table-1). Out of 44 species recorded, the maximum number of organisms recorded belonged to Ascomycetes. The 38 fungi that were more frequently isolated for these studies were Acremonium byssoides, Alternaria alternate, Alternaria brassicola, 
Aspergillus candidus, Aspergillus flavus, Aspergillus fumigates, Aspergillus nidulanse, Aspergillus niger, Aspergillus ochraceus, Aspergillus oryzae, Aspergillus parasiticus, Aspergillus terreus, Chaetomium funicola, Chaetomium globosum, Chaetomium indicum, Cladosporium cladosporioides, Cladosporium oxysporum, Curvularia pallescence, Drechslera hawaiiensis, Drechslera rostrata, Drechslera specifer, Epicoccum purpurascence, Eurotium amestaldomi, Fusarium equiseti, Fusarium moniliforme, Fusarium oxysporum, Fusarium pallidoroseum, Fusarium solani, Neosartoria fischeri, Nocosmospora vasinfecta, Paecilomyces variotii, Penicillium chrysogenum, Penicillium citrinum, Penicillium oxalicum, Phoma glomerata, Trichoderma virense, Trichoderma viride, Verticillium alboatrum. Besides these, 5 fungal forms Absidia cylindrospora, Gongronella butleri, Mucor hiemalis, Mucor racemosus, Rhizopus stolonifer were isolated and recorded from Zygomycetes. Only 1 fungus was isolated from Basidiomycetes; Rhizoctonia bataticola. Fungi are ubiquitous achlorophyllous and heterotrophic organisms, which are directly influenced by environmental factors. They are cosmopolitan in occurrence and are found in rivers, and occur commonly on decomposing organic matter. Excessive levels of nutrients and other chemicals lead to changes in aquatic life (D. Dudgeom, et.al.,2006) .

In which Ascomycetes is a dominant order. The Ascomycota are represented in all land ecosystems worldwide, occurring on all continents including Antarctica. Spores and hyphal fragments are dispersed through the atmosphere and freshwater environments, as well as ocean beaches and tidal zones. (Laybourn \&Parry J., J 2009).

In the present study the most common fungi obtained in four distinct stations were Ascomycetes; Chaetomium indicum, Cladosporium cladosporioides, Cladosporium oxysporum, Epicoccum purpurascence, Neosartoria fischeri, Trichoderma virense and Zygomycetes; Absidia cylindrospora, Mucor hiemalis, Mucor racemosus. Acremonium byssoides, Drechslera hawaiiensis, Fusarium pallidoroseum, was present only in kotni station, Chaetomium globosum was found in pulgaon chowk and, Verticillium alboatrum was obtained in chattagarh station.

Physicochemical characteristics greatly influence to the diversity of fungi. Station - II had a higher diversity of fungi than station - I. It may be due to the unpolluted nature of water was encountered at this station (Ayodhya D Kshirsagar and Venkat R Gunale, 2013). The species richness and conidial production was higher in the unpolluted station. Similar results were reported from (Au et al.1992) in Hong Kong. However the lowest distribution of fungi was recorded in the station - I, III and IV, this was may be due to the polluted nature of the water. Similar observation recorded by Tan and Lim, 1983.

\section{Conclusion:-}

A total of 44 fungal taxa belonging to class Ascomycetes, basidioycetes and Zygomycetes were isolated and identified from Shivnath River at Durg district of Chhattisgarh. The study of biodiversity on the edge elucidates the relationships between organism and environment, and unravels the mechanisms of adaptation to extreme environment condition.

\section{References:-}

1. Aneja, K.R. 2001. Experiment in Microbiology, Plant Pathology, Tissue culture and Mushroom ProductionTechnology. New Age International Limited, 568pages.

2. Au, D.W.T., Vrijmoed, L.L.P. and Hodgkiss, I.J. 1992. Fungi and cellulolytic activity associated with decomposition of Bauhinia purpurea leaf litter in apolluted and unpolluted Hong Kong waterway.Canadian Journal of Botany., 70 : 1071 1079.

3. Ayodhya D Kshirsagar* and Venkat R Gunale, Diversity of Aquatic Fungi from Mula River at Pune City, IJALS, volume 6, issue-3, may (2013) ISSN:2277-758X

4. D. Dudgeom, A. Arthington, M. Gessner, Z. Kawabata, D. Knowler, C. Leveque, R. Naimen and C.Stullivan, (2006). Biological Review, 81 ; 163-182..

5. Hawksworth, D.L. (1991) The fungal dimension of biodiversity: magnitude significance and conservation. Mycol. Res. 95, 641-55.

6. Laybourn-Parry J.J. "Microbiology. No place too cold". (2009). Science 324 (5934): 1521-22.

7. O.D. Dhingra, J.B. Sinclair Basic plant pathology methods, CRC Press, Boca Ratón, FL (1985) p. 261

8. Oliveira,L. G. De; Maria A de; Q Cavalcanti; J Z de O Passavante; M J dos S Fernandes; D M de M Lima (2011)Filamentous fungi isolated from Candeias Beach, Pernambuco, Brazil. Hoehnea .38 (2):340-352.

9. Tan, T.K. and Lim, G. 1983. Effects of water pollution on fungi of submerged organic debris. Mycopathology., 82(2) : 121 124. 